\title{
GRAPHENE OXIDE OPTIMIZATION SYNTHESIS FOR APPLICATION ON LABORATORY OF UNIVERSIDADE FRANCISCANA ${ }^{1}$ OTIMIZAÇÃO DE SÍNTESE DE ÓXIDO DE GRAFENO PARA APLICAÇÃO EM LABORATÓRIO DA UNIVERSIDADE FRANCISCANA
}

\section{Theodoro da Rosa Salles ${ }^{2}$, Higor de Bitencourt Rodrigues ${ }^{3}$, Franciele da Silva Bruckmann ${ }^{4}$, Lauro Cezar Santos Alves ${ }^{5}$, Sérgio Roberto Mortari ${ }^{6}$ e Cristiano Rodrigo Bohn Rhoden ${ }^{7}$}

\begin{abstract}
Graphene oxide (GO) is a 2D material derived from graphene, having a hexagonal arrangement crystal structure together with the addition of various oxygenated functional groups, epoxides, alcohols, ketones, carbonyls and carboxyls. Hummers and Offeman, reported in 1958 a synthesis method that is still employed to the present day, only with few adaptations. Thus, graphite is oxidized by treatment with potassium permanganate and sodium nitrate in concentrated sulfuric acid. Recently our research group evaluated several methodologies described in the literature, about the current synthesis of GO and the respective adaptations and improvements to the Hummers method. And based on these literary accounts, we developed a synthesis mechanism that could be applied in standard laboratory conditions attending demands for further research using the GO, which demonstrated good yield with simple purification method and relatively short time to synthesis.
\end{abstract}

Keywords: improvement, manufacture, development.

\section{RESUMO}

O óxido de grafeno (GO) é um material $2 D$ derivado do grafeno, possuindo uma estrutura cristalina com arranjo hexagonal juntamente com a adição de diversos grupos funcionais oxigenados, epóxidos, álcoois, cetonas, carbonilas e carboxilas. A partir de 1958, Hummers e Offeman, desenvolveram o método de síntese que é utilizado e adaptado até os dias atuais. No qual, o grafite é oxidado pelo tratamento com permanganato de potássio e nitrato de sódio em ácido sulfúrico concentrado. Recentemente nosso grupo de pesquisa avaliou metodologias descritas na literatura, sobre as atuais sínteses de GO e as respectivas adaptações e aprimoramentos ao método de Hummers. E, com base nesses relatos literários, desenvolvemos uma estratégia de síntese que envolvesse a logística de laboratório minimalista e que atendesse as demandadas para posteriores pesquisas envolvendo o GO sintetizado, o qual demonstrou bom rendimento, com métodos simples de purificação e tempo relativamente curto para sintese.

Palavras-chave: aperfeiçoamento, fabricação, desenvolvimento.

\footnotetext{
${ }^{1}$ Study developed at the graduation

${ }^{2}$ Graduation student at the Universidade Franciscana- UFN. E-mail: theodoro.rsalles@gmail.com

${ }^{3}$ Chemical Engineer. E-mail: higordebitencourt@gmail.com

${ }^{4} \mathrm{MsD}$ student at the Nanoscience Posgraduate Program - Universidade Franciscana (UFN). E-mail: francielebruckmann2@, gmail.com

${ }^{5}$ Chemical Engineer. E-mail: laur04lves@gmail.com

${ }^{6}$ Colaborators - Nanoscience Posgraduate Program -Universidade Franciscana (UFN). E-mails: mortari@ufn.edu.br

${ }^{7}$ Correspondent Autor: Nanoscience Posgraduate Program - Universidade Franciscana (UFN). E-mail: cristianorbr@, gmail.com
} 


\section{INTRODUCTION}

Graphene oxide (GO) consists of the derivation of graphene material, in an oxidized format, functionalized by carboxyl, hydroxyl, carbonyl and epoxy groups, which provide the processability of the material in aqueous solution. The unique properties of GO have attracted attention for its usefulness as an additive and performance upgrade for composites, structural reinforcement in fibers, energy storage devices, molecular sieves, liquid crystal optical materials (DONG et al., 2017). Due to its 2D structure functionalized with oxygen-containing groups, GO can be superimposed layer by layer, to form macroscopic films (DONG et al., 2017). In biotechnology, carbon allotropes derivatives besides its applications have demonstrated to be a large field for studies regarding bioactivity (VIANA et al., 2019).

In relation to production costs (use of equipment and energy for an excess of time) the most critical step to produce GO is purification. This stage has many warehouses for the synthesis of a final quality product and depends essentially on the capacities of each GO production and the equipment available, to carry out the processes (DIMIEV, 2016).

Purification can be carried out by long processes of washing with water and using acid $(\mathrm{HCl})$ to remove metal ions (CHEN et al., 2016). After each wash cycle, GO is separated by generally centrifuging processes. When washing and removing impurities and decreasing the acid concentration, the product exfoliates in single layers, characteristic for the formation of GO, generating a stable and bulky colloid solution. Dispersions of GO tend to obtain this gelatinous aspect whereas the value of $\mathrm{pH}$ increases during washing procedures. Solvents such as acetone can be used in this step to suppress the formation of this gelatinous aspect (KRISHNAN et al., 2012). Alternatively, dialysis can be used for purification, involving specific equipment. This protocol step increases the purification time of the material, also raises costs, so it is recommended only for the synthesis of small quantities (DIMIEV, 2016).

In this study, experiments were carried out to determine the GO synthesis using graphite flakes - 100 mesh - graphite in this size range can be considered large, and therefore favors the formation of GO with an extensive size ( $>10 \mu \mathrm{m})$, promising for the manufacture of 2D layer structures, and 3D graphene-based networks. In those cases, GO sheets induce less interaction between them, thus favoring better mechanical properties. GO films also have better electrical and thermal conductivities, when compared to their small size (DONG, L. et al., 2017; CHEN et al., 2016). The purification step was based on minimalist methods both regarding to equipment and the complexity of techniques to be employed. This method shows to be able to result in high separation and washing efficiency.

The Charpy-Hummers method, used in this research context, together with the graphite size limited to 100 mesh, with improvements in the synthesis preparation and purification protocols according to the operating conditions of the laboratories provided by the Universidade Franciscana (UFN), characterize the synthesis as an efficient approach to produce GO in the laboratories of the 
University, without high costs and encouraging the local research. The main objective was to achieve a trouble-free, low-cost GO preparation protocol with considerable yield of oxidized material, less damage to the crystalline structure and consuming minimal time, energy and easy purification.

\section{MATERIALS AND METHODS}

\section{GO SYNTHESIS}

GO can be synthesized by graphite oxidation and exfoliation. Starting from 1958, (HUMMERS and OFFEMAN) developed the most generic method to produce GO, which is the most used and adapted today (MARCANO, 2010). In this method, graphite is oxidized by treatment based on potassium permanganate and sodium nitrate solubilized in concentrated sulfuric acid (DIMIEV; TOUR, 2014; POH et al., 2012). The adaptation of the synthesis used in this study is based on the Charpy-Hummers method. The method consists of 2 steps for graphite oxidation and formation of graphene oxide (GO) (CHEN et al., 2019).

The first step is characterized by the slow addition of permanganate $\left(\mathrm{Mn}_{2} \mathrm{O}_{7}\right.$ and $\left.\mathrm{MnO}_{3}^{+}\right)$under the solution of sulfuric acid and graphite, in this step there is the formation of $\mathrm{H}_{2} \mathrm{SO}_{4}$-GIC (graphite intercalation compound), which is the intercalation stage from sulfuric acid through graphene sheets (which make up graphite), an arrangement which is necessary for the formation of PGO (pristine graphite oxide), the oxidized structure of graphite (DIMIEV, 2016). This step also determines the exfoliation yield, which depends on the exposure time of graphite in the oxidizing solution, due to the presence of graphite bisulfate, qualified as responsible for the increase in exfoliation (CHEN et al., 2019).

The second oxidation step $\left(\mathrm{MnO}_{4}^{-}\right)$takes place during the addition of distilled water to the reaction system, the step is identified by increasing the thermal stability of the GO. The extension of this stage provides an increase in hydroxyl groups, which are thermally more stable than epoxy groups that make up the GO (KANG et al., 2016). However, there is a selective formation of carboxylic groups $(\sim 4.1 \%)$ and an increase in defects in the GO structure with an increase in temperature above 70 to $95^{\circ} \mathrm{C}$ (LI et al., 2018; CHEN et al., 2016). At temperatures below $45^{\circ} \mathrm{C}$, there are no significant changes in the structure of GO sheets (KANG et al., 2016).

All experiments had the addition of graphite in flakes $(1 \mathrm{~g})$, sulfuric acid $(60 \mathrm{~mL})$ and potassium permanganate $(6 \mathrm{~g})$. From the syntheses carried out (alternating variables such as temperature, time, amount of solvent and purification) it was possible to predict the most effective method to produce GO. In operational matters, the temperature used was $40{ }^{\circ} \mathrm{C}$, an adequate temperature to prevent potential deformation of the material's crystalline structure (KANG et al., 2016).

Typical procedure (1), graphite $(1 \mathrm{~g})$ and $98 \%$ sulfuric acid $(60 \mathrm{ml})$ were added in a beaker $(500 \mathrm{ml})$ under magnetic stirring $(150 \mathrm{rpm})$ and the solution was stirred for 30 minutes at $20{ }^{\circ} \mathrm{C}$ (A). 
Sequentially, potassium permanganate $(6 \mathrm{~g})$ was added slowly, over a period of 20 minutes, maintaining the temperature of the suspension at $20^{\circ} \mathrm{C}$, and stirred for another 10 minutes (B). Afterwards, the reaction was heated to $40{ }^{\circ} \mathrm{C}$ for different time intervals for all four experiments (C) (Table 1).

In the experiment 2 , the heating was turned off after $5 \mathrm{~h}$ and $20 \mathrm{~mL}$ of $98 \%$ sulfuric acid was added (there was the formation of a very dense liquid, the acid was added to aid in the stirring), and the solution was kept under stirring at room temperature for additional $1 \mathrm{~h}$ (D).

In the experiment 3 , after 4-5 hours of stirring, it was observed the formation of a very dense solution, making it difficult the stirring of the system, however no amount of acid was added in the next $22 \mathrm{~h}$ under heating (E). Then $180 \mathrm{ml}$ of distilled water were dripped into the reaction system and maintained for an additional $1 \mathrm{~h}$ at $40{ }^{\circ} \mathrm{C}(\mathbf{F})$.

For the experiments 1 and 2, $300 \mathrm{~mL}$ of distilled water was used to maintain the 1:3 ratio (CHEN, Ji et al., 2016).

For the experiment 3, stirring was continued at room temperature for an extended time after adding $180 \mathrm{~mL}$ of distilled water $(23 \mathrm{~h})$, before heating (Table 1$)$.

Finally, for the experiment 4, $180 \mathrm{~mL}$ of distilled water was added, and the temperature was maintained at $40{ }^{\circ} \mathrm{C}$ for $2 \mathrm{~h}(\mathbf{G})$. All The experimental reactions were completed by filling it up to $500 \mathrm{~mL}$ of the beaker with distilled water at $20^{\circ} \mathrm{C}$ and adding $10 \mathrm{~mL}$ of $\mathrm{H}_{2} \mathrm{O}_{2}$ to reduce $\mathrm{Mn}$ (VII) permanganate species.

Table 1 - Relevant experiments for syntheses of graphene oxide.

\begin{tabular}{ccc}
\hline Experiments & $\mathbf{1}^{\mathbf{0}}$ Oxidation step & $\mathbf{2}^{\circ}$ Oxidation step \\
\hline 1 & $5 \mathrm{~h}-40{ }^{\circ} \mathrm{C}$ & $1 \mathrm{~h}-40{ }^{\circ} \mathrm{C}$ \\
2 & $5 \mathrm{~h}-40{ }^{\circ} \mathrm{C} ; 1 \mathrm{~h}-25^{\circ} \mathrm{C}$ (D) & $1 \mathrm{~h}-40{ }^{\circ} \mathrm{C}$ \\
3 & $22 \mathrm{~h}-40{ }^{\circ} \mathrm{C}(\mathrm{E})$ & $23 \mathrm{~h}-25^{\circ} \mathrm{C} ; 1 \mathrm{~h}-40{ }^{\circ} \mathrm{C}(\mathrm{F})$ \\
4 & $5 \mathrm{~h}-40{ }^{\circ} \mathrm{C}$ & $2 \mathrm{~h}-40{ }^{\circ} \mathrm{C}(\mathrm{G})$ \\
\hline
\end{tabular}

\section{GO PURIFICATION}

All the reactions were decanted with $2 \mathrm{~L}$ of distilled water 2 times to reduce the concentration of sulfuric acid, and then decanted with $2 \mathrm{~L}$ of $1: 10 \mathrm{v} / \mathrm{v} \mathrm{HCl}$ solution for removing side products, metal ions mostly. Reactions products 1 and 2 were again decanted with $2 \mathrm{~L}$ of distilled water 2-3 times and centrifugated, about 2-3 times at 6 hours intervals. For reactions 3 and 4, only decantation with distilled water ( 5 times) was used. This process was carried out only with the intention of correcting the $\mathrm{pH}$ approaching to 7 (PENG et al., 2015). Afterwards, all reaction products were dried in an oven at $60^{\circ} \mathrm{C}$ for 24 hours (PAULCHAMY; ARTHI; LIGNESH, 2015). The GO films obtained were cutting and grinding for size reduction (PAULCHAMY, B., ARTHI, G., LIGNESH, B. D., 2015). The powder obtained were used for characterization and yield calculations. 


\section{GRAPHENE OXIDE YIELD DETERMINATION}

After the heating step, the GO was obtained in the form of a thin film, which easily became powder after macerating. The weight of the GO powder acquired in relation to the graphite mass used, considering all the losses occurred in the purification and powdering procedures of the material to provide the yield of the GO synthesis $\left(\mathrm{Y}_{\mathrm{GO}}\right)$, so that, $Y_{G O}=\left(\frac{m_{G O}}{m_{G r}}\right) \times 100 \%$, where $\mathrm{m}_{\mathrm{GO}}$ is the mass of the dry GO powder obtained (in $\mathrm{mg}$ ) and $\mathrm{m}_{\mathrm{Gr}}$ is the mass of graphite used (in $\mathrm{mg}$ ) (CHEN et al., 2016).

\section{SYNTHESIS CHARACTERIZATIONS}

All syntheses performed were accomplished by XRD, FTIR analyzes aiming to visualize essential parameters for the formation of GO during the synthesis, with the materials and equipment available at UFN laboratories

Fourier transform infrared spectroscopy (FTIR) was attenuated to the main experiments to determine the functional groups and chemical bonds present in the samples, using the Fourier transform infrared spectrometer Varian 640-IR Fourier Transform Spectroscopy Infrared South Africa. Bruker Optics D2 Advence USA equipment was used for the characterization using X-ray diffraction (XRD), in order to determine the crystalline phases of the samples and assist in proving that the synthesis of this study was efficient for the formation of GO.

\section{AVERAGE SIZE OF CRYSTALLITE AND DEGREE OF CRYSTALLINITY}

The average size of the crystallite (D) is related to the width of the half height of the diffracted peaks and the mesh parameter associated with the position of the peaks is given by Equation (1) by Scherrer (1939) (SCHERRER, 1939):

$$
D=\frac{K \lambda}{\beta \cos \theta}
$$

Where, $\mathrm{D}$ is the average crystallite size, $\mathrm{K}$ is the constant that depends on the shape of the particles, the wavelength of the electromagnetic radiation, $\theta$ the diffraction angle and $\beta$ the width of the peak height (FWHM). The degree of crystallinity of the samples was calculated using the reported method by Navarro-Pardo et al. (NAVARRO-PARDO et al., 2013):

$$
C I=\frac{A c}{A c+A a}
$$

Ac is the área of the cristalline peaks, and Aa is the área of the amorphous cavities in the samples (NAVARRO-PARDO et al., 2013). 


\section{RESULTS AND DISCUSSION}

\section{GO SYNTHESIS}

The volume of sulfuric acid $(60 \mathrm{~mL})$ was assigned in order to ensure sufficient heat and mass transfer for the complete oxidation of graphite in flakes, considering 100 mesh as a large size graphite (CHEN et al., 2016. A). The amount of $6 \mathrm{~g}$ of $\mathrm{KMnO} 4$ was attributed to guarantee a complete oxidation of the precursor material in the requested time, the $3 \mathrm{~g}$ usually used by other bibliographies, for the case of this study, was consumed completely before the conversion of graphite into PGO, therefore, the amount of $6 \mathrm{~g}$ was necessary (LI et al., 2018). The additional hydrolysis (second oxidation step) in a 1:3 diluted sulfuric acid solution (by volume), it was found out to being an essential step for exfoliation of graphite oxide (GrO) into a GO (loss of the c-axis layer for the formation of a single layer atomic) (CHEN et al., 2016. A) (CHEN et al., 2016. B). Was applied for hydrolysis of sulfur species contained in the reaction medium (mainly organosulfates). GO sheets can be covalently linked by organosulfates, leading to incomplete exfoliation of graphite oxide (CHEN et al., 2016). The temperature of $40-50{ }^{\circ} \mathrm{C}$ was attributed to not compromise the GO's crystalline structure, based on the temperature used by CHEN et al., 2019 and also taking into account that temperatures close to $50{ }^{\circ} \mathrm{C}$ are a safe operating range for GO manufacturing, enabling high yield with excellent quality of the material (LI et al., 2018). The addition of water by dropwise for the start of the second oxidation step is essential, the sudden addition of water excessively increases the temperature of the reaction system, which compromises the crystalline structure of the product (CHEN et al., 2019) (CHEN et al., 2016).

The x-ray diffractogram of the experiment 1 showed an incomplete oxidation of the starting material, which can be concluded through the DRX analysis (X-ray diffractometry) by the angle $2 \theta$ $\sim 26^{\circ}$ (DIMIEV; TOUR, 2014), characteristic of remaining graphite, the DRX standard for complete oxidation of the material and formation of the GO is defined by the angle $2 \theta \sim 10^{\circ}(001)$ (DIMIEV; TOUR, 2014). The addition of $180 \mathrm{~mL}$ of water completed the first oxidation step (D), $5 \mathrm{~h}$ at $40^{\circ} \mathrm{C}$ and $1 \mathrm{~h}$ at room temperature, which was defined as insufficient time. In the experiment 3 , relatively long time was used for the first oxidation step. The graphite in contact with the oxidizing agent for an excess of time helped in the oxidation of the material, being possible to visualize that there was no remaining starting material, analyzed by the angle $2 \theta \sim 26^{\circ}$ (002) (Figure 1) (DIMIEV; TOUR, 2014). However, it presented other signals of interference like the experiment 1, this due to the inefficient purification. 
Figure 1 - X-ray diffractogram of expirements.

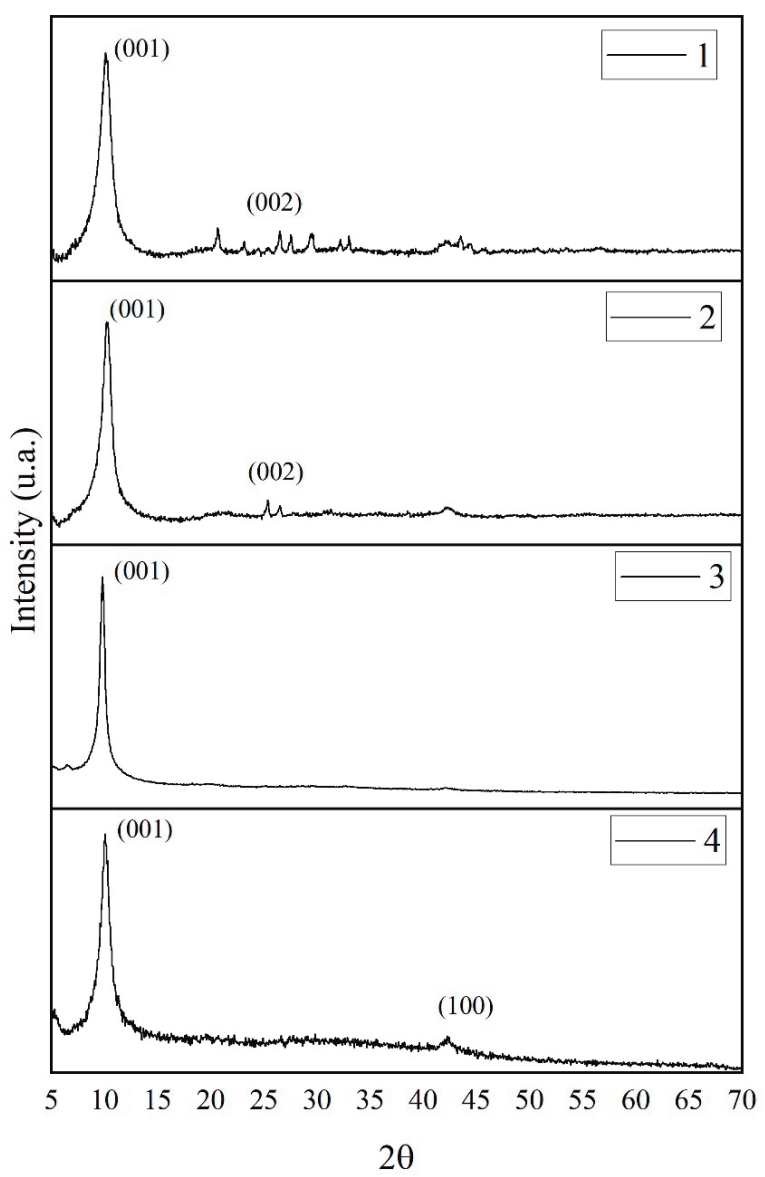

Source: Author's construction.

The XRD of the experiment 3, characterized by the longer reaction time, both for the first oxidation step (E) and during the second step (F), allowed the visualization of the complete oxidation, when only the angle $2 \theta \sim 10^{\circ}(001)$ was identified, characteristic for the plane of GO (Figure 1) (DIMIEV; TOUR, 2014). Finally, the experiment 4, the same reaction time, as for experiment 2, was maintained, however with the change in the second oxidation step $(\mathbf{G}), 2 \mathrm{~h}$ at $40^{\circ} \mathrm{C}$. The signal around $2 \theta \sim 42^{\circ}(100)$ indicated a small distance between the graphene layers (STOBINSKI et al, 2014), in addition to the signal $2 \theta \sim 10^{\circ}$ (001) (KAUFMANN JR, 2020).

The FTIR analyzes showed different functional groups. The most intense band identified around $3407 \mathrm{~cm}^{-1}$ refers to the $\mathrm{O}-\mathrm{H}$ stretch, indicating the presence of functional groups $\mathrm{OH}$ and/ or $\mathrm{COOH}$ in the structure of the materials. The small band identified around $3227 \mathrm{~cm}^{-1}$ is due to the asymmetric or symmetrical elongation of the $\mathrm{C}-\mathrm{H}$ bond. Vibrational elongation of $\mathrm{C}=\mathrm{O}$ is identified around $1636 \mathrm{~cm}^{-1}$, the acute peak found at $1615 \mathrm{~cm}^{-1}$ is a resonance peak that can be attributed to the stretching and flexion of the vibration of $\mathrm{OH}$ groups of water molecules adsorbed in GO. The signal around $1381 \mathrm{~cm}^{-1}$, denotes $\mathrm{C}-\mathrm{OH}$ groups. Vibrational elongation of $\mathrm{CO}$ alkoxy groups can also be observed around $1099 \mathrm{~cm}^{-1}$, functional groups and chemical bonds that are characteristic of the oxidized composition of the graphene material (KHALILI, 2016) (RHODEN et al., 2017) (BERA et al., 2018). 
Figure 2 - Infrared spectrum of expirments.

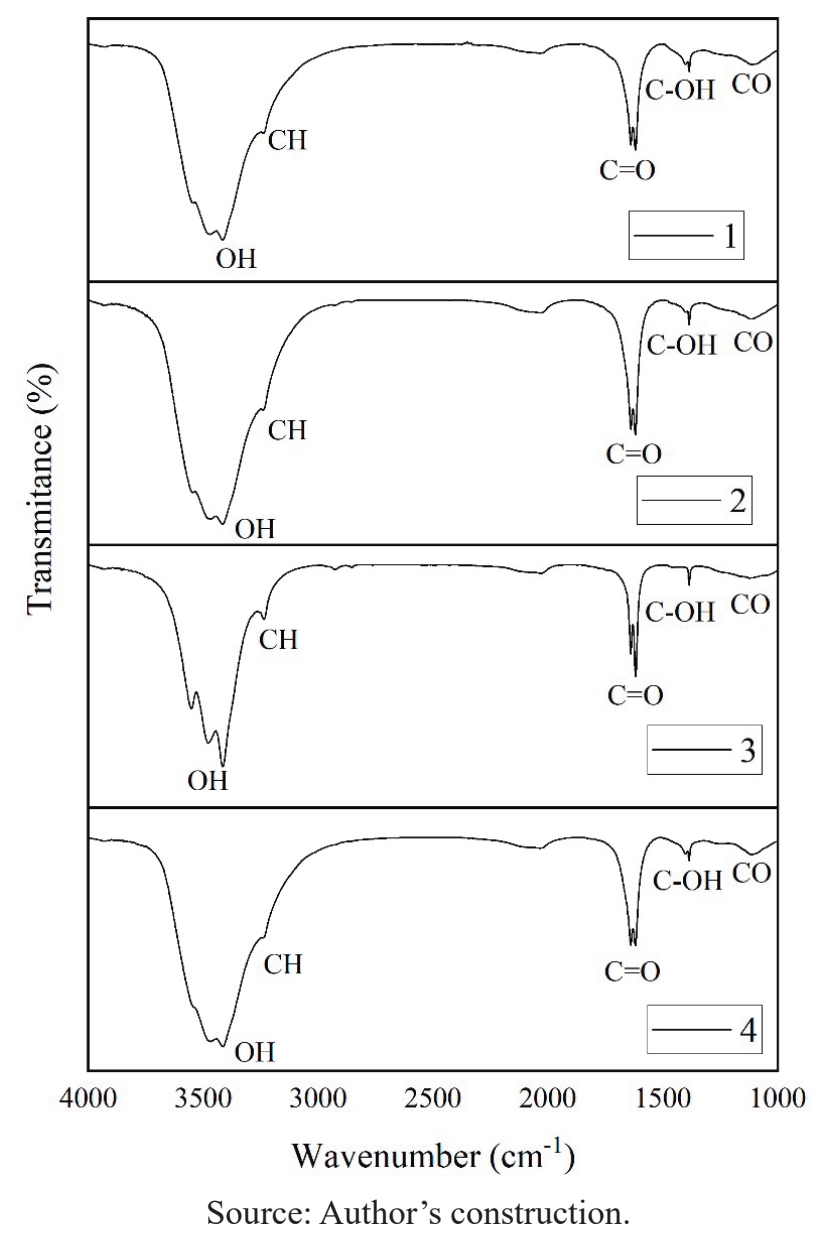

GO PURIFICATION

An important observation in the literature refers to the variability and complexity of the methods for purifying the synthesized GO (DIMIEV, 2016). In this work, the aim was to use low equipment complexity with consequently low costs.

For all syntheses, the decantation procedure was applied. However with the use of centrifugation in experiments 1 and 2, and only decantation by gravity for experiments 3 and 4 . The syntheses in which the centrifugation was used, required many hours (about $6 \mathrm{~h}$ ) for separation and became less practicable for use on the laboratory. The performance of synthesis 1 and 2 may also have been compromised by the use of the centrifuge, needing several material overflows in centrifuge tubes for each centrifugation, and eventual loss of residual material at every step. For syntheses 3 and 4, only the decantation procedure was used, this method, although simple, proved to be quite viable, requiring no monitoring, and relatively little separation time (average $12 \mathrm{~h}$ ). Decantation also avoids loss of synthesized product, and several GO replacements are not required. The decanting method, however, implies that the material must be fully oxidized and exfoliated, since through decantation no further auxiliary exfoliation method is no longer possible - unlike the purification processes (agitation, 
centrifugation) where it is still possible to convert GrO to GO, as well as their separation (CHEN et al., 2016). Thus, for experiments 3 and 4 the second oxidation step (hydrolysis) $\mathbf{F}$ and $\mathbf{G}$ was extended, assisting in the complete formation of $\mathrm{GrO}$ in $\mathrm{GO}$, without requiring more complex procedures, such as the use of centrifugation, or agitation during purification processes, or even the use of ultrasound, which can also compromise the material's crystalline structure and compromise the final product (CHEN et al., 2016; DIMIEV, 2016).

\section{GO YIELD DISCUSSION}

The yield of the syntheses performed (ratio of the mass of GO obtained by the mass of graphite used) was $145.7 \%$ for the synthesis 2 , which does not necessarily correspond to the integral mass of $\mathrm{GO}$, considering the interferences observed in the x-ray diffractogram. For the synthesis 3 a total of $1.747 \mathrm{~g}$ of GO was obtained, corresponding to $175 \%$ yield (attributed by the exaggerated mass of reagents and complete oxidation of the material). For the synthesis 4 a total of 1,698 $\mathrm{g}$ of GO was obtained, corresponding to $169 \%$ of yield, which corresponds to the complete oxidation of the material and the large number of reagents used. For the synthesis 1 the yield was not considered because there was a lot of interference, in addition to residual graphite demonstrated in the analysis of the diffractogram, not certifying fidelity in the result.

The synthesis also showed relatively higher yields compared to several methods reported in the literature, for example, considering the synthesis of CHEN et al., 2016. A., (the highest yield of the referenced articles) which presented a value of $152 \%$ in its synthesis using small size high quality graphite.

\section{AVERAGE SIZE OF CRYSTALLITE AND DEGREE OF CRYSTALLINITY}

The degree of crystallinity of the experiments decreased as the oxidation steps lasted longer (mainly the second oxidation step), this fact is explained by the temperature used $\left(40^{\circ} \mathrm{C}\right)$, since it proved to be safe for the production of high quality GOs, however causing damages in the crystalline structure of the materials (CHEN et al, 2019), see Table 2. It is important to point out that GO crystallinity also influenced by exposure time to different oxidative species $\left(\mathrm{MnO}_{3}^{+}\right.$and $\left.\mathrm{MnO}_{4}^{-}\right)$in a concentrated sulfuric acid solution (JALILI et al., 2014).

Table 2 - Degree of crystallinity of the samples and average crystallite size.

\begin{tabular}{ccc}
\hline Synthesis & Degree of crystallinity (\%) & Average size of crystallite (nm) \\
\hline $\mathbf{1}$ & 85.82 & 8.92 \\
$\mathbf{2}$ & 69.40 & 8.77 \\
$\mathbf{3}$ & 68.62 & 14.45 \\
$\mathbf{4}$ & 52.06 & 7.43 \\
\hline
\end{tabular}


The use of graphite in flakes as a starting material for the synthesis of GO requires a longer time of oxidation and chemical exfoliation during the synthesis. Since this precursor material has a high size, this interferes directly with the average crystallite dimension of the obtained materials (SHOJAEENEZHAD; FARBOD; KAZEMINEZHAD, 2017). Synthesis 1 presented the smallest average crystallite size, in addition to an impure product, since the oxidation steps comparing with the oxidation steps employed in the other experiments. In synthesis 3 , however, even with high oxidation times, the product presented the largest size, in addition to a pure material as observed in the X-ray diffractogram.

\section{CONCLUSION}

An extremely simple method of producing graphene oxide has been developed, with minimal energy expenditure, and ensuring complete oxidation of the material and exfoliation - only during the synthesis process for the GO formation. The synthesis reported in this work showed a $175 \%$ yield, furnishing a very high quality graphene oxide from a low-quality graphite as a starting material. The highlight of this methodology is its simplicity, low energy and logistical costs, efficiency, and quality of the final synthesized material. This material shown to be suitable for further biological as well as material applications.

\section{REFERENCES}

AJDARI, F. B. et al. Melamine-functionalized graphene oxide: Synthesis, characterization and considering as pseudocapacitor electrode material with intermixed POAP polymer. Applied Surface Science, v. 459, p. 874-883, 2018.

BERA, M. et al. Facile one-pot synthesis of graphene oxide by sonication assisted mechanochemical approach and its surface chemistry. Journal of nanoscience and nanotechnology, v. 18, n. 2, p. 902-912, 2018.

CHEN, H. et al. Efficient room-temperature production of high-quality graphene by introducing removable oxygen functional groups to the precursor. Chemical science, v. 10, n. 4, p. 1244-1253, 2019.

CHEN, J. et al. Water-enhanced oxidation of graphite to graphene oxide with controlled species of oxygenated groups. Chemical science, v. 7, n. 3, p. 1874-1881, 2016. 
CHEN, J. et al. Synthesis of graphene oxide sheets with controlled sizes from sieved graphite flakes.

Carbon, v. 110, p. 34-40, 2016.

DIMIEV, A. M. Mechanism of formation and chemical structure of graphene oxide. Graphene Oxide: Fundamentals and Applications, p. 36, 2016.

DIMIEV, A. M.; TOUR, James M. Mechanism of graphene oxide formation. ACS nano, v. 8, n. 3, p. 3060-3068, 2014.

DONG, L. et al. Synthesis and reduction of large sized graphene oxide sheets. Chemical Society Reviews, v. 46, n. 23, p. 7306-7316, 2017.

HUMMERS JR, W. S.; OFFEMAN, Richard E. Preparation of graphitic oxide. Journal of the american chemical society, v. 80, n. 6, p. 1339-1339, 1958.

JALILI, R; et al. Formation and processability of liquid crystalline dispersions of graphene oxide. Materials Horizons, v. 1, n. 1, p. 87-91, 2014.

KAUFMANN JR, C. G. K. et al. One-step synthesis of carbon nanoflowers by arc discharge in water. Ceramics International, v. 46, n. 16, p. 26229-26232, 2020.

KANG, J. H. et al. Hidden second oxidation step of Hummers method. Chemistry of Materials, v. 28, n. 3, p. 756-764, 2016.

KHALILI, D. Graphene oxide: a promising carbocatalyst for the regioselective thiocyanation of aromatic amines, phenols, anisols and enolizable ketones by hydrogen peroxide/KSCN in water. New Journal of Chemistry, v. 40, n. 3, p. 2547-2553, 2016.

KRISHNAN, D. et al. Energetic graphene oxide: challenges and opportunities. Nano today, v. 7, n. 2 , p. 137-152, 2012.

LI, C. et al. Controlled synthesis of graphite oxide: Formation process, oxidation kinetics, and optimized conditions. Chemical Engineering Science, v. 176, p. 319-328, 2018. 
NAVARRO-PARDO, F. et al. Effects on the thermo-mechanical and crystallinity properties of nylon 6, 6 electrospun fibres reinforced with one dimensional (1D) and two dimensional (2D) carbon. Materials, v. 6, n. 8, p. 3494-3513, 2013.

PENG, Li et al. An iron-based green approach to 1-h production of single-layer graphene oxide. Nature communications, v. 6, p. 5716 - 5725, 2015.

PAULCHAMY, B.; ARTHI, G.; LIGNESH, B. D. A simple approach to stepwise synthesis of graphene oxide nanomaterial. Journal of Nanomedicine \& Nanotechnology, v. 6, n. 1, p. 1 - 4, 2015.

SCHERRER, P. Bestimmung der inneren Struktur und der Größe von Kolloidteilchen mittels Röntgenstrahlen. In: Kolloidchemie Ein Lehrbuch. Springer, Berlin, Heidelberg, 1912. p. 387-409.

RHODEN, C. R. B. Síntese de análogos de peptídeos incorporados a materiais nanoparticulados de carbono funcionalizados via reações multicomponentes. 2018. 107f. Tese de Doutorado (Doutor em Nanociências), Universidade Franciscana, 2018.

RHODEN, C. R. B. et al. Síntese fácil e direta do óxido de grafeno magnético. Disciplinarum Scientia Naturais e Tecnológicas, v. 18, n. 2, p. 389-397, 2017.

SHOJAEENEZHAD, S. S.; FARBOD, M.; KAZEMINEZHAD, I. Effects of initial graphite particle size and shape on oxidation time in graphene oxide prepared by Hummers' method. Journal of Science: Advanced Materials and Devices, v. 2, n. 4, p. 470-475, 2017.

STOBINSKI, L. et al. Graphene oxide and reduced graphene oxide studied by the XRD, TEM and electron spectroscopy methods. Journal of Electron Spectroscopy and Related Phenomena, v. 195, p. 145-154, 2014.

VIANA, A. R. et al. Cytotoxicity study of graphene oxide against vero lineage cells. Disciplinarum Scientia Naturais e Tecnológicas, v. 20, n. 3, p. 355-364, 2019.

YOGESH, G. K. et al. Synthesis, characterization and bioimaging application of laser-ablated graphene-oxide nanoparticles (nGOs). Diamond and Related Materials, v. 104, p. 107733, 2020. 